Original Research Paper

\title{
Rock Fall Hazard Zonation in Haraz Highway
}

\author{
${ }^{1}$ Hadi Jarahi and ${ }^{2}$ Sedigheh Seifilaleh \\ ${ }^{1}$ Seismic Expert, Department of Tunnel 2, Harazrah Consulting Engineers CO., Tehran, Iran \\ ${ }^{2}$ Geophysics Ms.C, Tehran University, Tehran, Iran
}

\author{
Article history \\ Received: 27-04-2016 \\ Revised: $30-04-2016$ \\ Accepted: 02-05-2016 \\ Corresponding Author: \\ Hadi Jarahi \\ Seismic Expert, Department of \\ Tunnel 2, Harazrah Consulting \\ Engineers CO., Tehran, Iran \\ Email: hadijarahi@gmail.com
}

\begin{abstract}
Takavar and Ebtehaj tunnels as part of Haraz highway are located in southwestern Damavand mount. Statistics show enormous financial and human damages in this route because of rockfall. Geological and topographical conditions, caused to the intensity of rockfall, because most of heights in this area covered by Damavand Trachyandesitic lava flows. In this study Rockfall Analyst (RA) software used to analysis risk modeling of rockfall in three-dimensional. In such a model, the spatial distribution of frequency, height velocity and energy of falling or rolling rocks are calculated. Then the layers in the same velocity, energy and height and the weight, were analyzed and finally 9 risk-prone regions were identified. However, except one of them, other areas need engineering solutions to drop the risk of rockfall.
\end{abstract}

Keywords: Damavand, Rockfall, RA Software

\section{Introduction}

Rockfall hazards along the mountain roads, has always been of interest to researchers in this field. Many studies have been done that are: Lied (1977) in Norway, Wieczorek et al. (1998) in a Youmist valley in the United States, Batterson et al. (2006) researches evaluating the geological risks related to rockfall in Canada, Guzzeti et al. (2004) studies in Italy. Rockfall is in the forms of free fall, jump or rolling which base on topography profile, it can be observed as two or more rockfall types (Topal et al., 2007).

Using GIS in rockfall study is effective in finding potential rockfall slopes and estimating the maximum distance that can flounce by rockfall (Jaboyedoff, 2003). Agliardi and Crosta (2003; Lan et al., 2007; Lan, 2011; Topal et al., 2007; Frattini et al., 2012a; 2012b; Valagussa et al., 2014; Margottini et al., 2016), recent studies have led to know the modern methods of 3D zoning rockfall hazard, especially for communication networks (Budetta, 2004). The recent earthquakes, according to Firuzkuh fault movements (Jarahi et al., 2016), has led to increasing rockfalls in the study area. In this study, we use Lan et al. (2007) method and RA software aims to study the rockfall hazard zonation in this part of Haraz highway.

\section{Study Area}

Haraz highway is one of the most important roads in Iran. This road connects Amol (a city in the north of Alborz Mountains) to Tehran in the south of the mountain (Entezam and Mehrnush, 1973). The study area is Takavar to Ebtehaj tunnels as a part of Haraz highway. This area is located about $3 \mathrm{~km}$ far from west of Abask village and on the western hillsides of Damavand (Fig. 1). This area has the main natural condition to create a range of rockfall, because of mountainous topography, tectonic activity, geological and climatically variety (Mousavi et al., 2011). This area adjacency (less than $20 \mathrm{~km}$ ) to Firuzkuh active fault (Jarahi et al., 2016), has a significant effect on rockfall and it ceases to form communities zones. The rough morphology of this area with cold and humid conditions and special geological conditions (Hutchinson, 1988), leads to many natural disasters in this region every year (Jarahi, 2015). One of the most common and damaging of these risks is rockfall (Mousavi et al., 2011). In this study, we try to find the prone rockfall areas and do the rockfall hazard zonation in the study area.

\section{Geology}

The study area is in central Alborz geological zone in range of Jurassic to Quaternary deposits (Allenbach and Steiger, 1972). Because of formations variety, tectonics, climate and proximity to large faults (Berberian, 2014), have caused to instability in this important communication highway and any part has a special characteristic. Study area is located near Damavand volcanic rocks. 


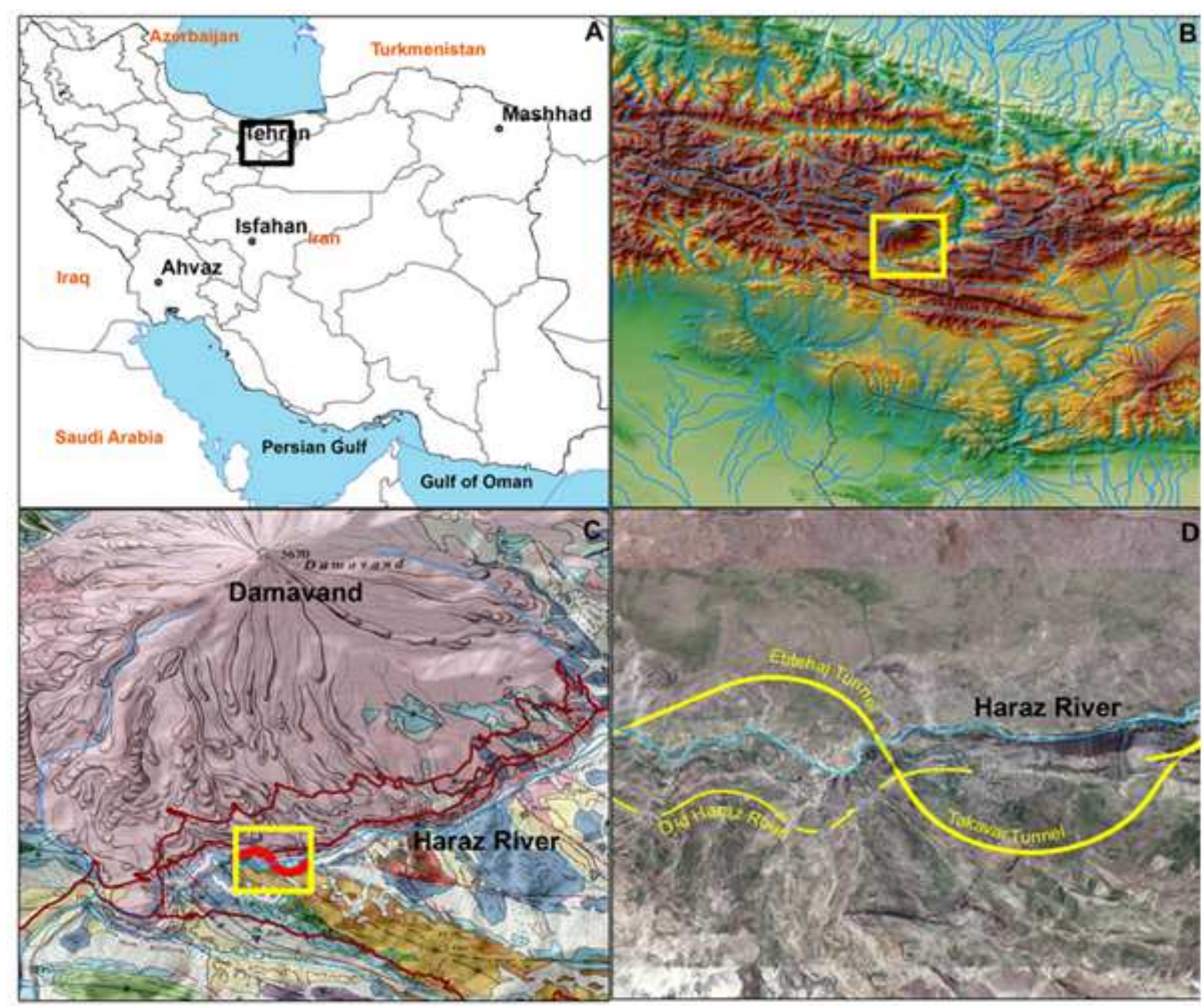

Fig. 1. Study area situation A: In the country B: In the Alborz Mountains, C: In the geology map of Damavand D: In the Quick bird satellite imagery

The older units in this zone are the alternative layers of the Marly limestone formation, Delichay (Doger) and Lar (Malm). Massive limestone after that there is red conglomerate formation Fajan (Paleocene), with unconformity boundary on the older layers. On the top of the units, there are Damavand volcanic rocks in the age of Quaternary and Andesit type to Andesit basalts (Allenbach and Steiger, 1972). Soft debris and Haraz river alluvial deposits are the other geological units in this area (Fig. 2).

\section{Rockfall Frequency in the Study Area}

According to the statistics (Jarahi, 2015), every year, more than 43 big rockfall cases occurred in this part of the Haraz highway (Fig. 3). Small Rockfalls are routine in winner days and they always have many human financial losses. Base on statistic data's, rockfalls caused more than one million dollars damages (including human and financial losses) in this area and especially in the study region.

\section{Analysis and Discussion}

\section{Determine the Location of the Rockfall}

The most important step in the rockfall analysis is to find the place that has potential for movement. Generally, determining these locations needs for engineering, geotechnical and topographic data. However, due to available software, using these facts to analysis is impossible, so we try to use field observation and engineering judgment to decide the potential places. The potential rockfall locations are identified based on field studies and Quick bird satellite imagery (Fig. 4). There are more than 130 locations that there are broken pieces, rocks falling on the highway. Moreover, due to climate and seismicity conditions; it may be move and treat Haraz highway. 


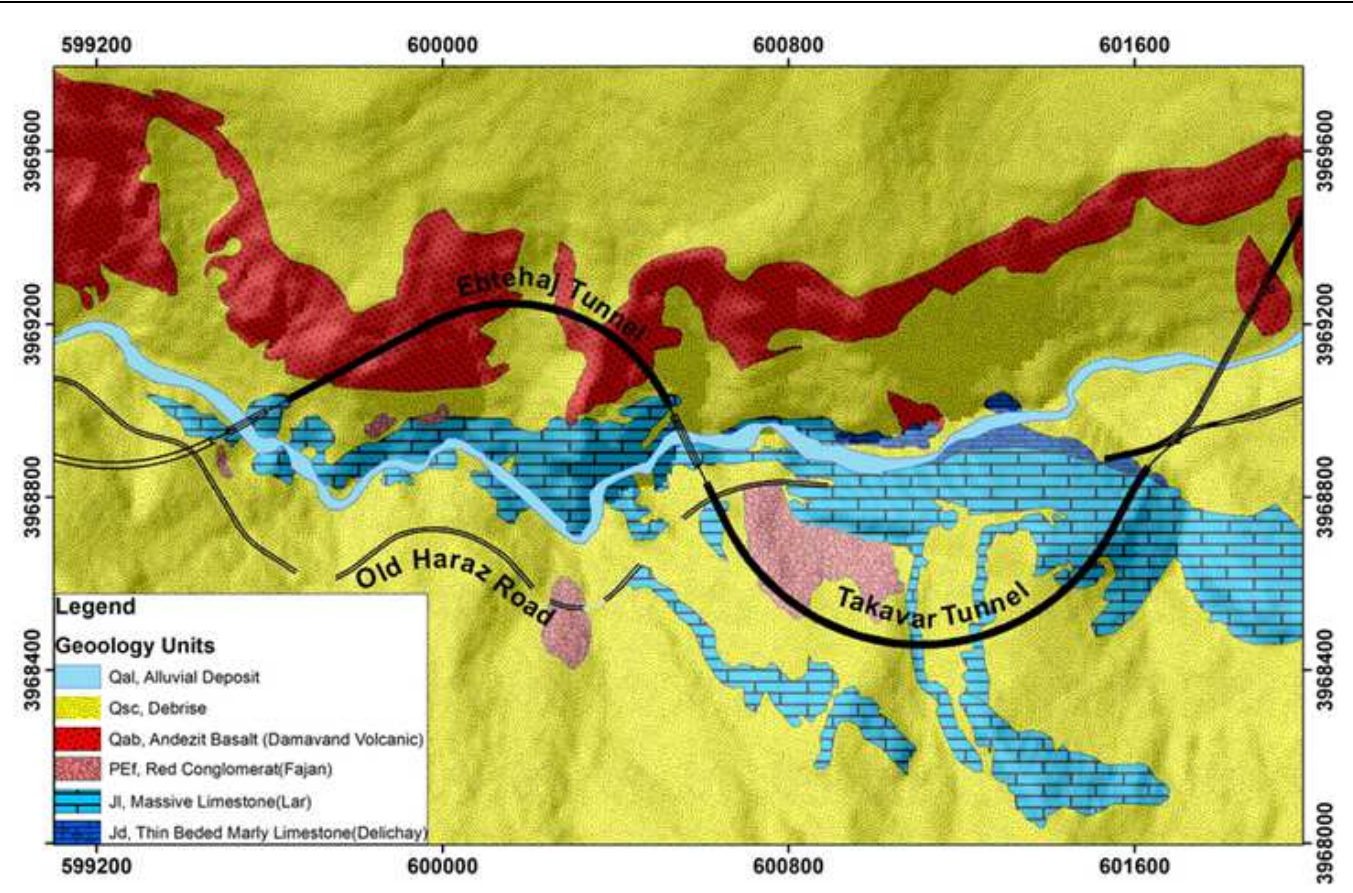

Fig. 2. Geological map of study area
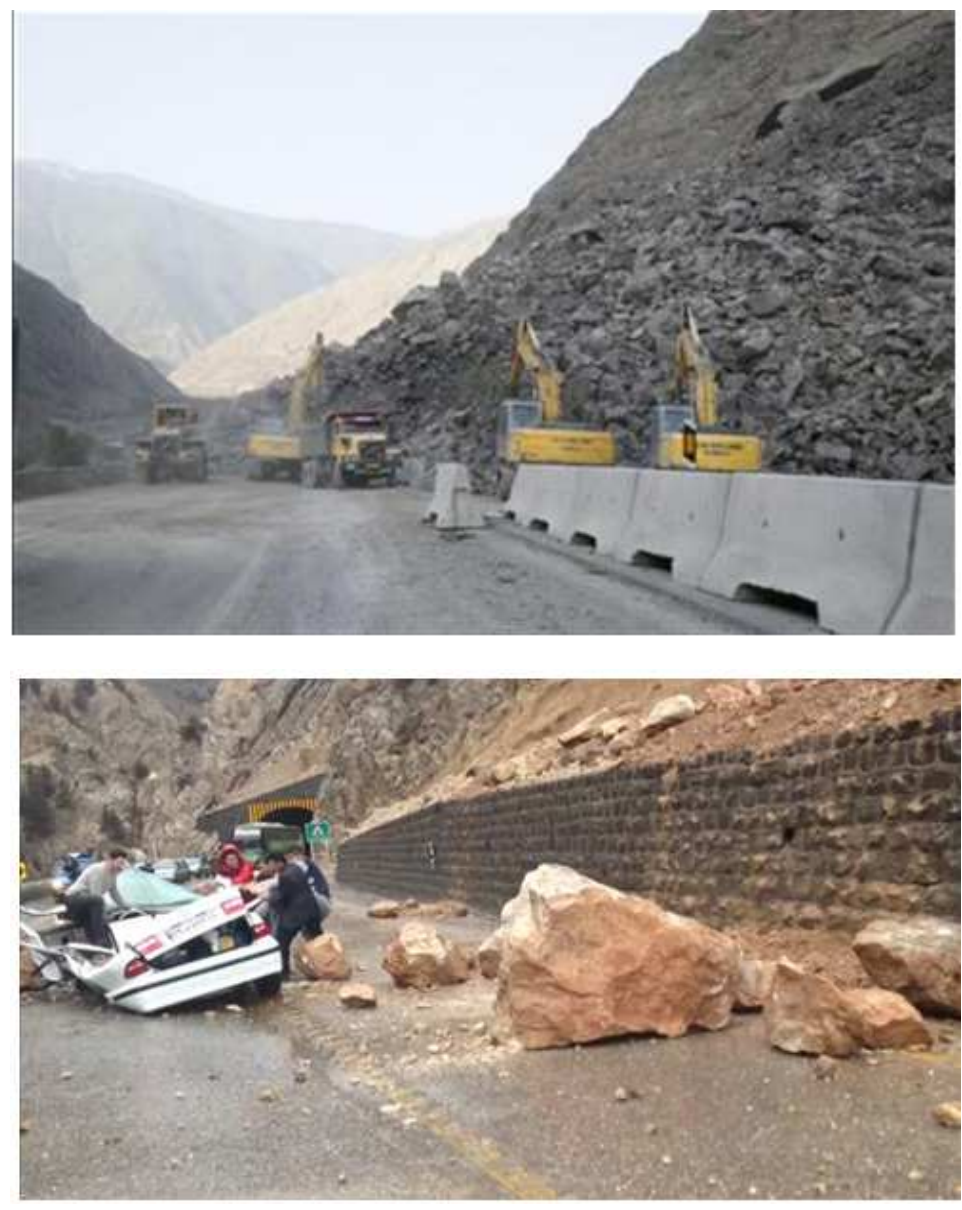

Fig. 3. Rockfall damages in Takavar and Ebtehaj tunnels in 2013 


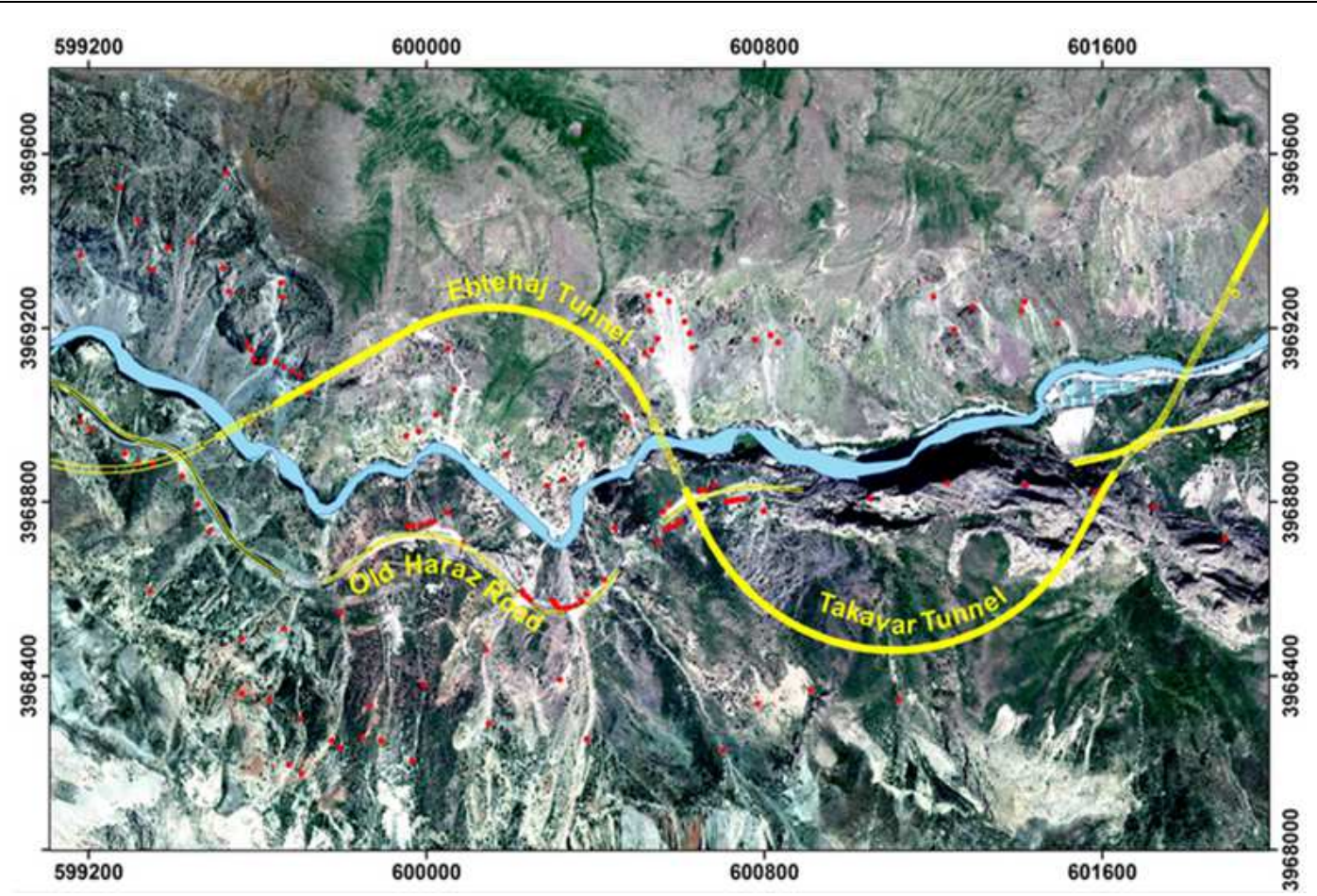

Fig. 4. Potential rockfall places on Quick bird satellite imagery

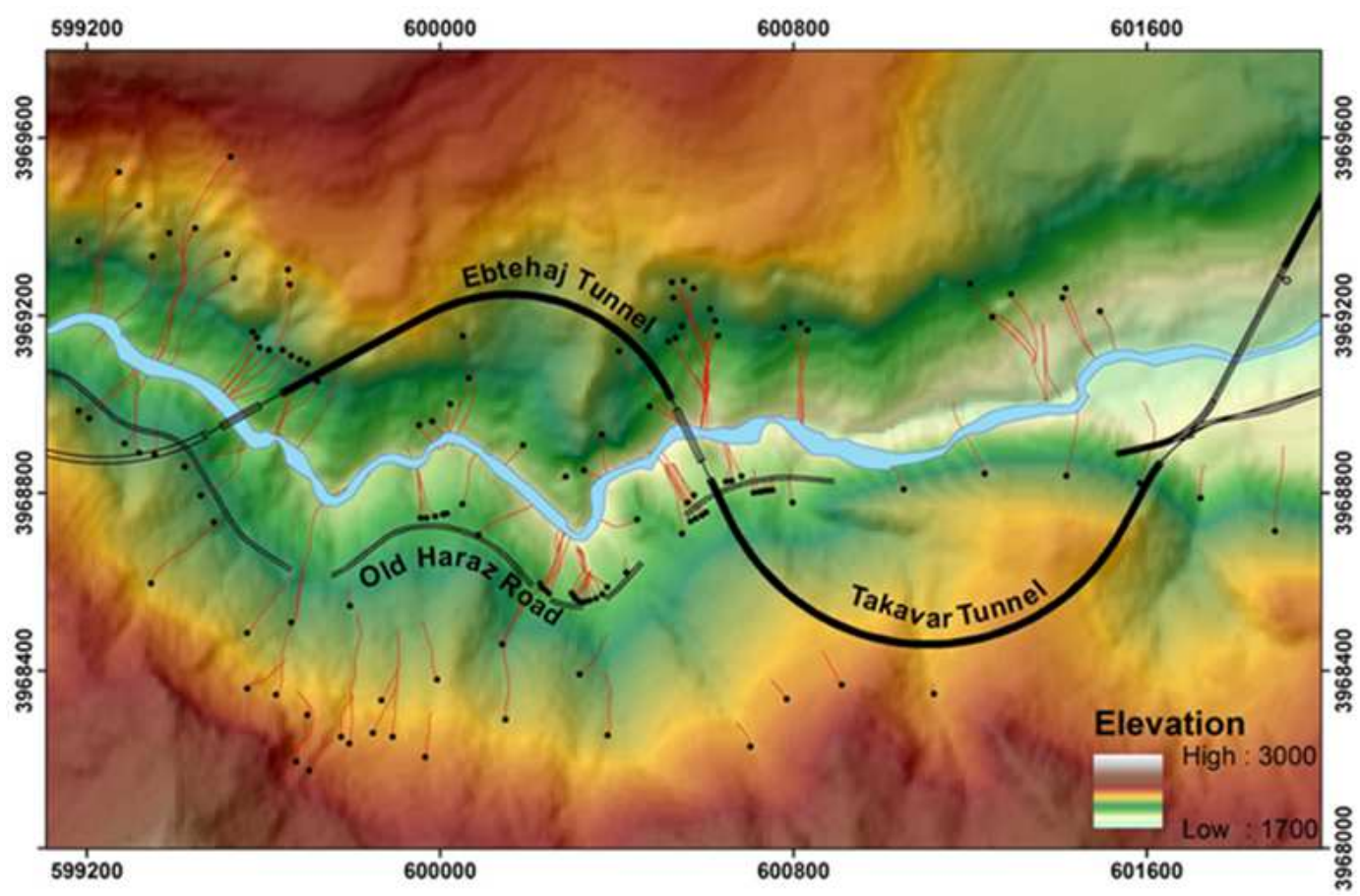

Fig. 5. Rockfall trajectory on DEM

\section{Engineering Characteristics of the Rock Mass}

The main step in the rockfall hazard analysis is the source surface and seeder trajectory. Therefore, in this section the main variable of the surface is determined according to rock units in Table 1 . These variables include angle of friction angle (Q), the normal restitution (Rt) and tangential restitution (Rt). 


\section{Rockfall Trajectory}

The next step is to decide the trajectory of rockfall. In order to find the trajectories, we need to input Digital Elevation Model (DEM) with $10 \mathrm{~m}$ accurately, the geological layers (Table 1) and seeder points. The RA software calculates the rockfall trajectory, as shown in Fig. 5. In this analysis the mass of seeder is $100 \mathrm{~kg}$, sampling distance for seeder along polyline is $1 \mathrm{~m}$ and density of rocks in $2600 \mathrm{~kg} / \mathrm{m}^{3}$. This parameter determined based on field observations and engineering judgment. Notice that these routes have third dimensional that includes movement type. This movement based on engineering seeder trajectory parameters that mentioned before can appear in the form of falling or rolling (Fig. 6).

Table 1. Material properties

\begin{tabular}{llll}
\hline Name rock unit & $\mathrm{Rn}$ & $\mathrm{Rt}$ & $\mathrm{Q}$ \\
\hline Lar Limestone & 0.50 & 0.95 & 40 \\
Dalichai Marly limestone & 0.45 & 0.90 & 35 \\
Fajan Conglomerate & 0.35 & 0.88 & 30 \\
Damavand Andesitebasalt & 0.50 & 0.95 & 40 \\
Debris & 0.30 & 0.80 & 25 \\
\hline
\end{tabular}

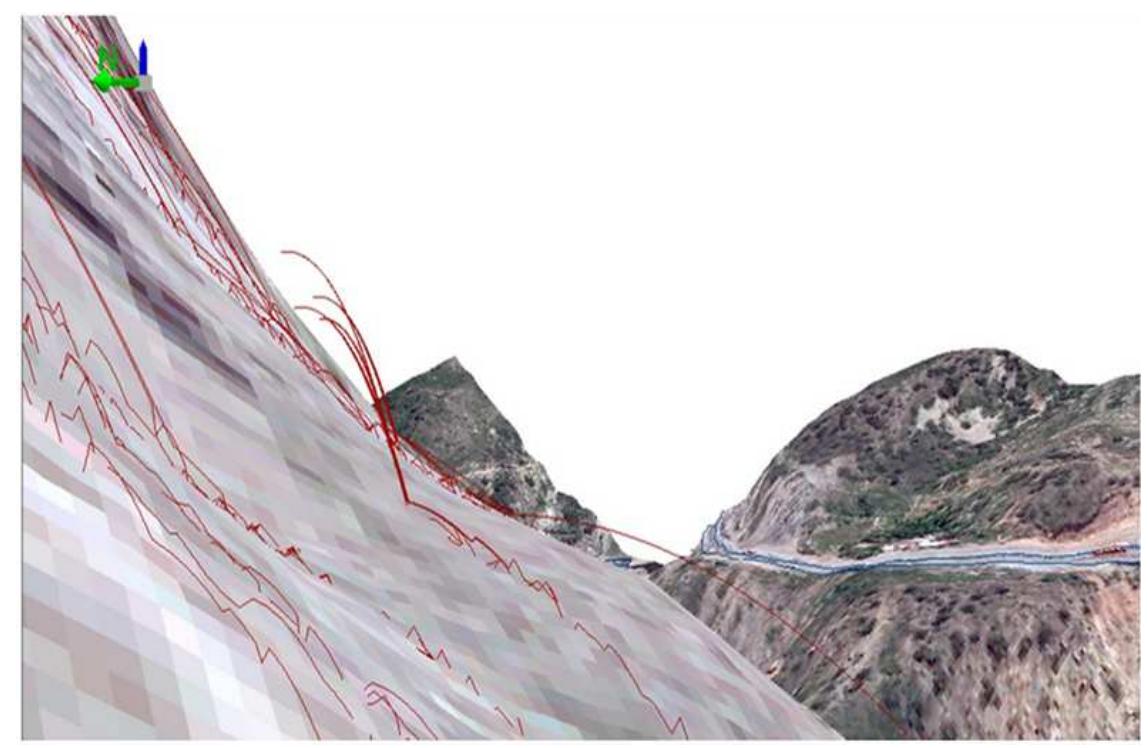

Fig. 6. Three-dimensional view of rockfall trajectory. Different seeder movements like falling or rolling are shown with brown lines

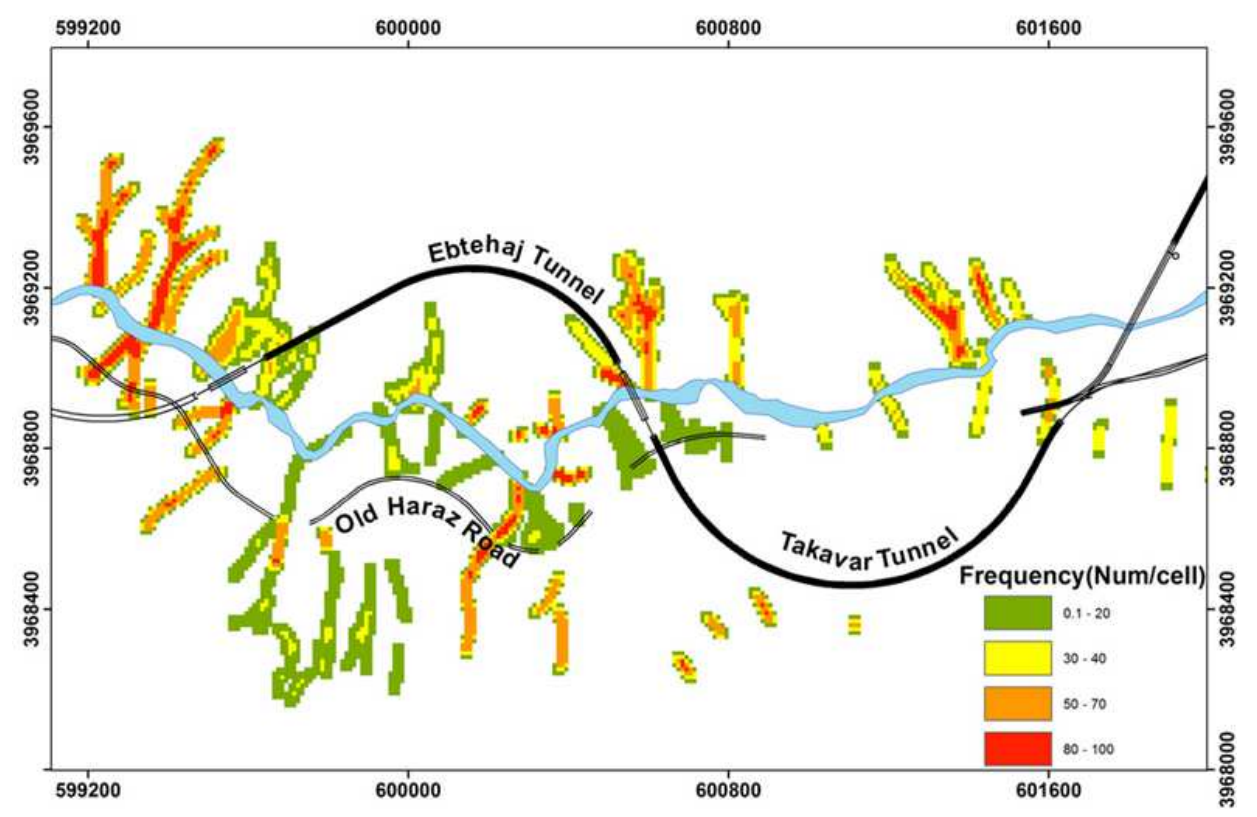

Fig. 7. Rockfall trajectory frequency 


\section{Rockfall Frequency}

The next step is rockfall frequency. In this section, RA software calculates the rockfall numbers to every networked unit (cells). The dimensions of these networks are determined about 10 meters according to DEM accuracy (Fig. 7).

\section{Rockfall Hazard Zonation}

In the final step, the information layers, which produced during software analysis and field observations, will use as input layers in the rockfall hazard analysis. These layers include rockfall frequency, (Fig. 7), Rockfall velocity (Fig. 8) rockfall height (Fig. 9) and rockfall energy (k/s2) (Fig. 10). It's necessary to weight the output layers for single rockfall hazard zonation layer. Therefore, the frequency, height and energy layers of rockfall have weighted respectively, $0 / 5,0 / 2$ and $0 / 3$. Finally, rockfall hazard zonation map in five different categories for the study area, as shown in Fig. 11. In this figure, nine areas are determined as the high-level rockfall hazard. These areas are located on entrance and exit of Ebtehaj and Takavar tunnels. Therefore, rockfall is possible on this part of Haraz highway. Table 2 shows the different parts of Haraz highway, according to rockfall hazard. Areas 2, 4 and 9 in Table 2 are shown in Fig. 12.

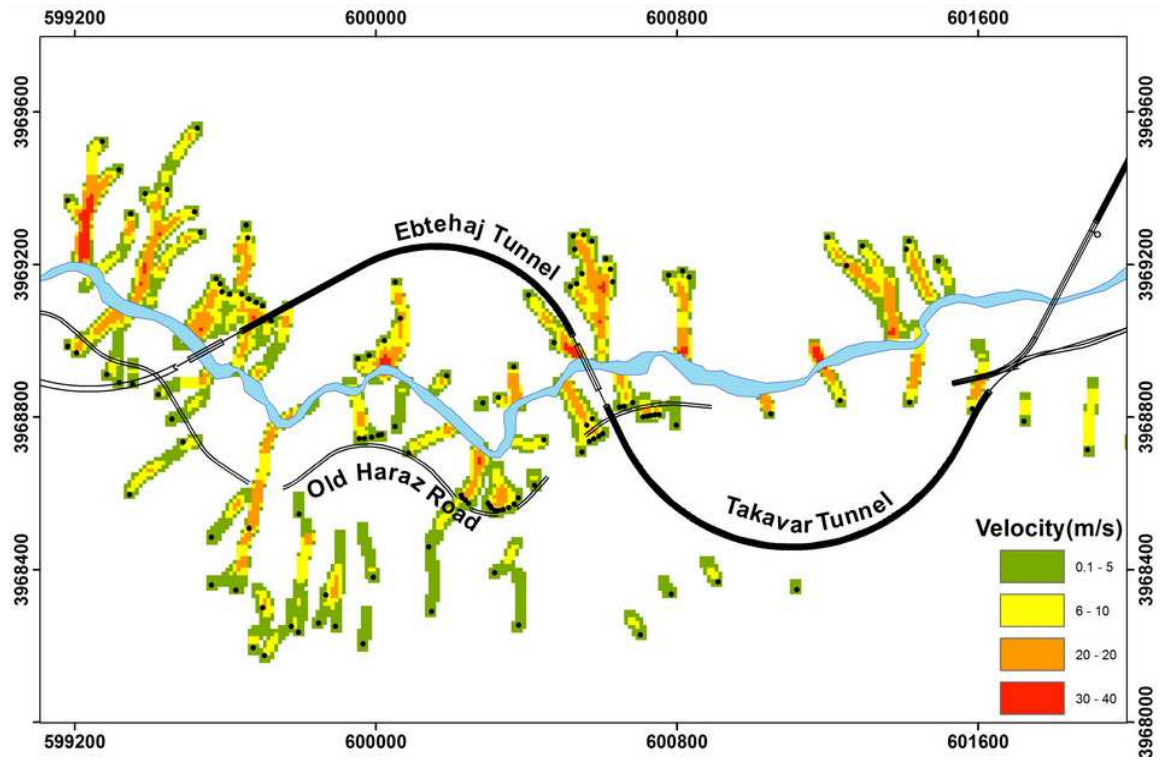

Fig. 8. Rockfall velocity

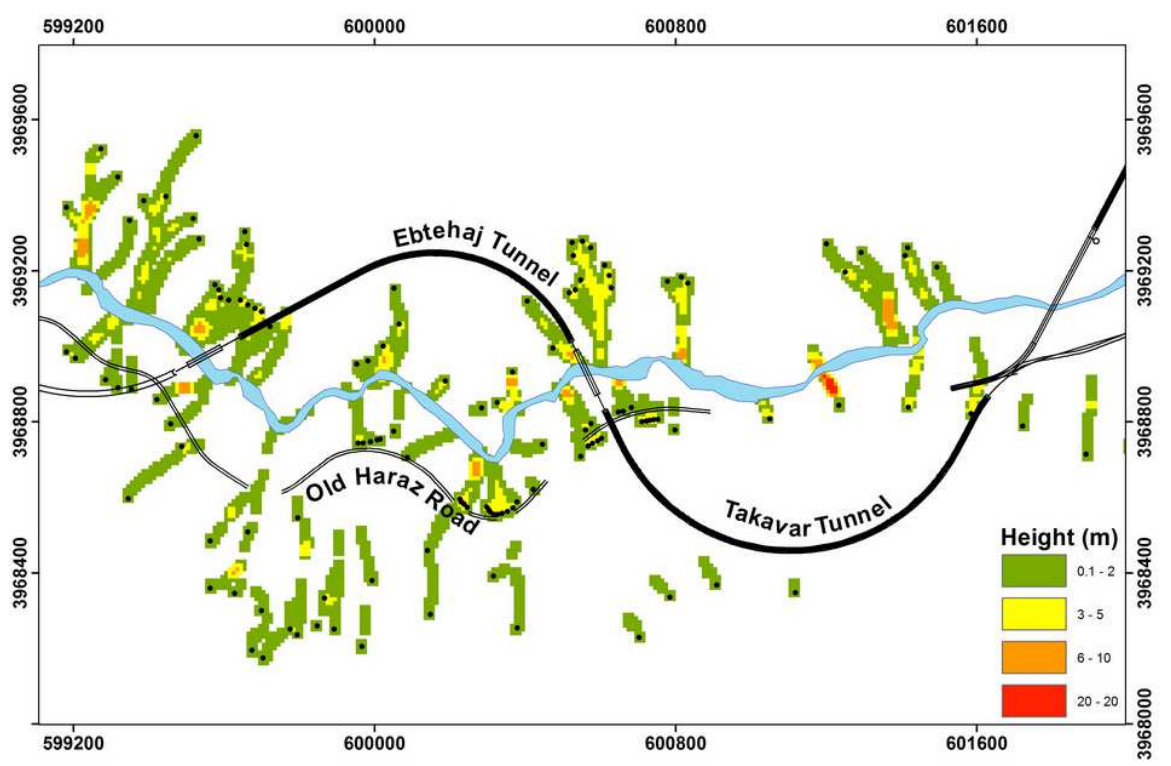

Fig. 9. Rockfall height 


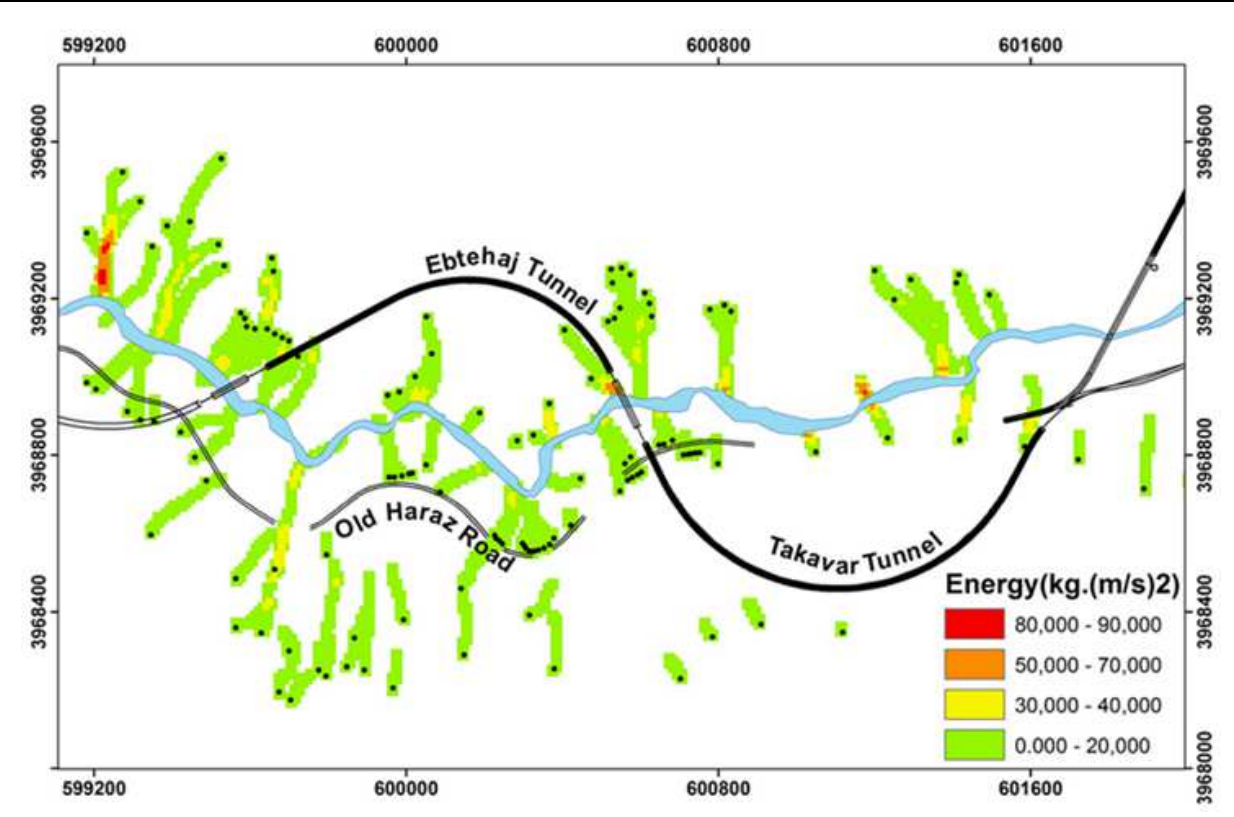

Fig. 10. Rockfall energy

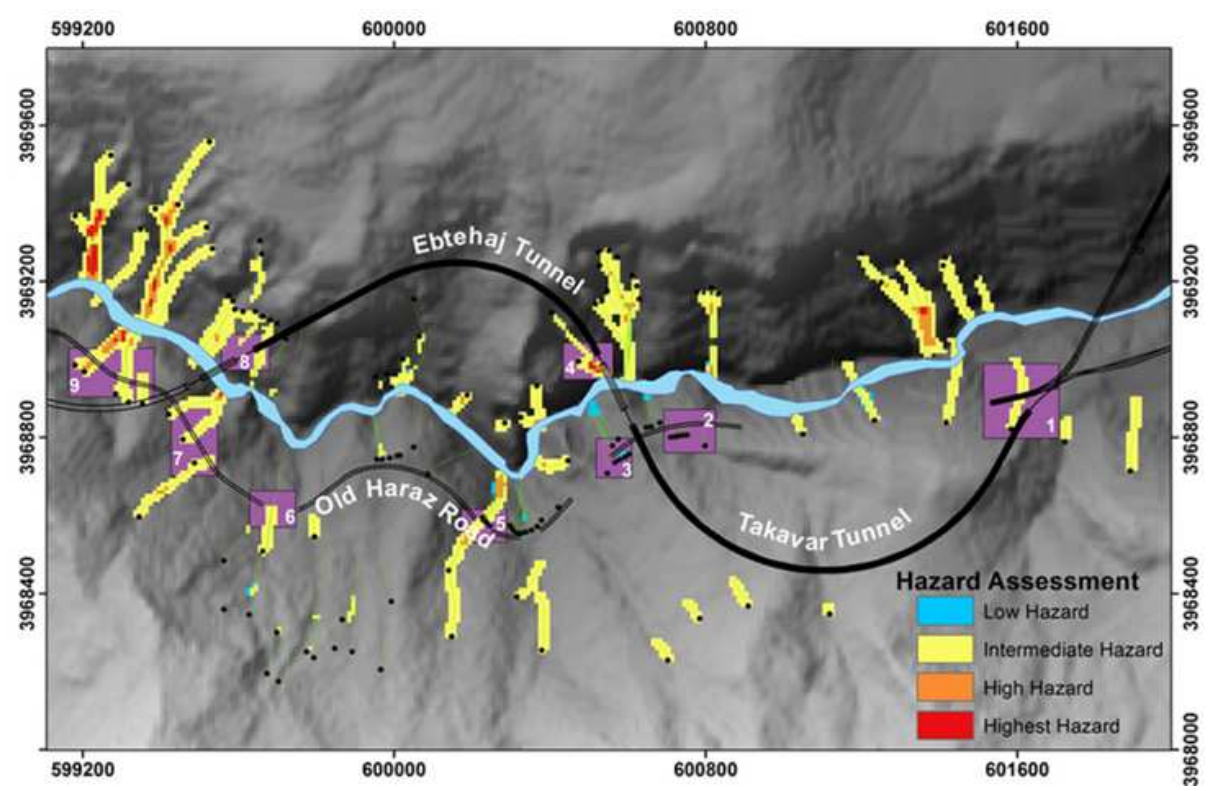

Fig. 11. Rockfall hazard zonation map of study area

Table 2. The risk of rockfall on the Haraz highway in the study area

\begin{tabular}{llll}
\hline Area & Hazard Level & On the rockfall route & Engineering measures necessity \\
\hline 1 & Safe & Yes & Yes \\
2 & Low & Yes & Yes \\
3 & High to Highest & Yes & Yes \\
4 & Intermediate to High & Yes & No* \\
5 & Intermediate & Yes & Yes \\
6 & Intermediate & Yes & Yes \\
7 & Intermediate & Yes & Yes \\
8 & Intermediate to High & Yes & Yes \\
9 & Intermediate & Yes & Yes \\
\hline
\end{tabular}

* The rockfall start from down side of Ebtehaj tunnel 

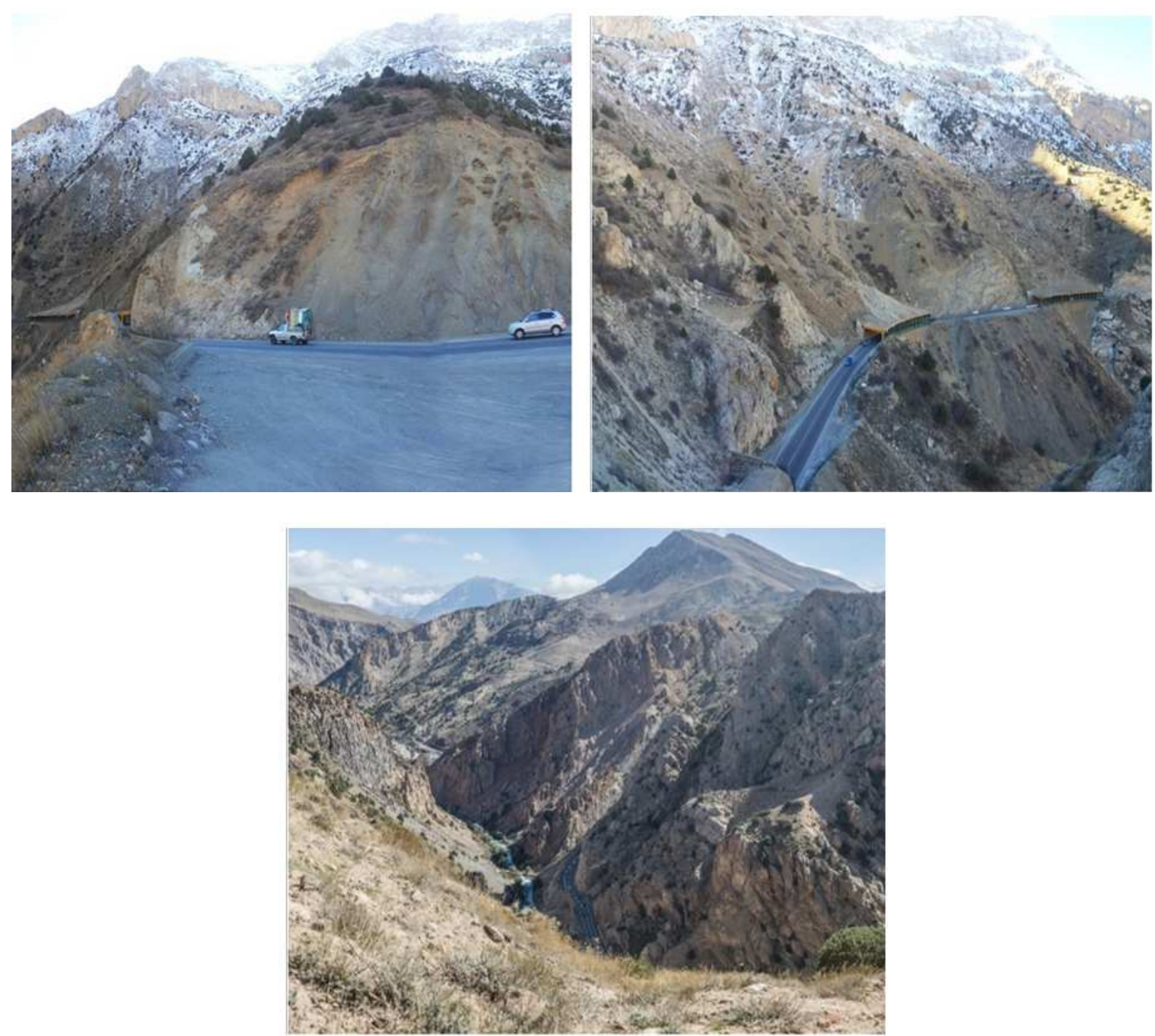

Fig. 12. A view of potential rockfall base on Fig. 11 results

In one part (area 4), some structures such as barrier walls are used to deal with rockfall hazard. However, in the other parts that are shown in Fig. 11 and Table 2, it is necessary to consider proper measures.

\section{Discussion and Conclusion}

In the present study, rockfall hazard zonation was studied on a part of Haraz highway. In this regard, nine areas were identified as high-risk area between them. There are two areas that they have engineered measures such as a barrier wall to keep rockfall. The seven remaining areas need to design and carry out the appropriate structures to prevent the rockfall hazard. It should be noted that the results of this study could be useful for selecting the way with the lowest risk of rockfall before the road construction. In addition, assessing the situation and predicting the seeder trajectory and rockfall occurrence, can use for most appropriate methods and technical solution to prevent rockfall or control and conducting the unstable rock mass. Therefore, we suggest authorities that they use this study result in Haraz highway improvement and modernization studies.

\section{Acknowledgment}

The authors thank and appreciate Dr. Lan from Alberta University to give RA software. In addition, special thanks to lady Shadi Salehi due to his valuable guidance in this research.

\section{Author's Contributions}

Hadi Jarahi: Developed the conceptual idea, designed the study, collected data and made the interpretation.

Sedigheh Seifilaleh: Edited the manuscript. 


\section{Ethics}

This article is original and contains unpublished materials. The corresponding author confirms that all of the other authors have read and approved the manuscript and there are no ethical issues involved.

\section{References}

Agliardi, F. and G.B. Crosta, 2003. High resolution three-dimensional numerical modelling of rockfalls. Int. J. Rock Mechan. Min. Sci., 40: 455-471. DOI: $10.1016 /$ S1365-1609(03)00021-2

Allenbach, P. and R. Steiger, 1972. Geological map of Damavand. Geological Survey of Iran.

Batterson, M., S. McCuaig and D. Taylor, 2006. Mapping and assessing risk of geological hazard on the Northeast Avalon peninsula and Humber valley, Newfoundland. Newfoundland and Labrador Department of Natural Resources, Geological Survey of Iran.

Berberian, M., 2014. Earthquakes and Coseismic Surface Faulting on the Iranian Plateau. 1st Edn., Elsevier Science, Oxford, ISBN-10: 0444632972, pp: 776.

Budetta, P., 2004, Assessment of rockfall risk along roads. Nat. Hazard Earth Syst. Sci., 4: 71-81. DOI: $10.5194 /$ nhess-4-71-2004

Entezam, A. and M. Mehrnush, 1973. Geological report and petrography of Damavand (Central AlborzIran). Geological Survey of Iran.

Frattini, P., G.B. Crosta and F. Agliardi, 2012a. Rockfall Characterization and Modeling. In: Landslides Types, Mechanisms and Modeling, Clague, J.J. and D. Stead (Eds.), Cambridge University Press, Cambridge, ISBN-13: 978-1-107-00206-7, pp: 267-281.

Frattini, P., G.B. Crosta, S. Lari and F. Agliardi, 2012b. Probabilistic Rockfall Hazard Analysis (PRHA). In: Landslides and Engineered Slopes: Protecting Society through Improved Understanding, Eberhardt, E.B. (Ed.), Taylor and Francis Group, London, ISBN-10: 0415633036, pp: 1145-1151.

Guzzeti, F., P. Reichenbach and S. Ghigi, 2004. Rockfall hazard and risk assessment along a transportation corridor in the Nera Valley, Central Italy. Environ. Manage., 34: 191-208. DOI: $10.1007 / \mathrm{s} 00267-003-0021-6$

Hutchinson, J. N., 1988. Morphological and Geotechnical parameters of landslides in relation to geology and hydrogeology, state-of-the-art report. Proceedings of the $5 \mathrm{~h}$ International Symposium on Landslides, (ISL' 88), A.A. Lausanne, Balkema, Rotterdam.
Lan, H., D.C. Martin and C.H. Lim, 2007. RockFall analyst: A GIS extension for three-dimensional and spatially distributed rockfall hazard modeling. Comput. Geosci., 33: 262-279.

DOI: $10.1016 /$ j.cageo.2006.05.013

Lan, H., 2011. Tutorial for Rockfall Process modeling using Rockfall Analyst. A 3D Rockfall Modeling Extension to ArcGIS 9.x,

Lied, K., 1977. Rockfall Problems in Norway. In: Rockfall Dynamics and Protective Work Effectiveness, ISMES Publ. n.90. Bergamo, pp: 51-53.

Margottini, C., D. Spizzichino, G.B. Crosta, P. Frattini and P. Mazzanti et al., 2016. Rock fall instabilities and safety of visitors in the historic rock cut monastery of Vardzia (Georgia). Proceedings of the International Workshop on Volcanic Rocks and Soils, (VRS' 16), CRC Press/Balkema, pp: 177-178.

Mousavi, S.M., B. Omidvar, F. Ghazban and R. Feyzi, 2011. Quantitative risk analysis for earthquakeinduced landslides-Emamzadeh Ali, Iran. Eng. Geol., 122: 191-203.

DOI: $10.1016 /$ j.enggeo.2011.05.010

Jaboyedoff, M., 2003. CONEFALL 1.0 User's Guide. Open report-Soft 01, Quanterra.

Jarahi, H., 2015. Engineering Geology Report of Ebtehaj and Takavar tunnels, Haraz Highway, Department of tunnel 2, Harazrah Co.

Jarahi, H., N. Naraghiaraghi and M. Nadalian, 2016. Short period spectral acceleration Zonation of Tehran a comparison between slip and activity rates data's. Am. J. Geosci. DOI: 10.3844/ofsp. 10450

Topal, T., M. Akin and U.A. Ozden, 2007. Assessment of rockfall hazard around Afyon Castle, Turkey. Environ. Geol., 53: 191-200. DOI: $10.1007 / \mathrm{s} 00254-006-0633-2$

Valagussa, A., P. Frattini and G.B. Crosta, 2014. Earthquake-induced rockfall hazard zoning. Eng. Geol., 182: 213-225.

DOI: 10.1016/j.enggeo.2014.07.009

Wieczorek, G.F., M.M. Morrissey, G. Iovine and J. Godt, 1998. Rockfall hazards in the Yosemite Valley. USGS, Open-File Report 98/467. 